This copy is author's original pre-print version and may slightly differ from the official published version.

Full citation:

Paulin, W., Belt, P., Mottonen, M., Harkonen, J. and Haapasalo, H. (2012) 'Action

research on high-tech SMEs entering the USA market', International Journal of

Entrepreneurship and Innovation Management, Vol.16, No.3/4, pp.209-225.

DOI: 10.1504/IJEIM.2012.051901

\title{
Action research on high-tech SMEs entering the USA market
}

\author{
William L. Paulin \\ Paulin Neal Associates, \\ 4088 Peninsula Drive, \\ Carlsbad, CA 92010 USA \\ E-mail: wpaulin@usa.net
}

\section{Pekka Belt*, Matti Mottonen, Janne Harkonen and Harri Haapasalo}

Department of Industrial Engineering and Management,

University of Oulu,

P.O. Box 4610,

FI-90014, Finland

E-mail: pekka.belt@oulu.fi

E-mail: matti.mottonen@oulu.fi

E-mail: janne.harkonen@oulu.fi

E-mail: harri.haapasalo@oulu.fi

*corresponding author

\begin{abstract}
High-tech SMEs are forced to rapidly enter global markets due to market fragmentation and fierce competition. The purpose of this article is to describe difficulties and potential solutions for these companies entering the US market. This study utilised action research to analyse 60 attempts of Finnish high-tech SMEs entering the US market to clarify what type of approaches have worked in practice and what have not. Managers of high-tech companies can learn from both, successful and failed cases, when considering their own internationalisation. This study indicates that companies ought to start their internationalisation process early, be proactive, and utilise the learning-bydoing method. Obtaining business knowledge of their target market, acquiring expertise to their board \& management and networking locally seems crucial for success. Companies should also spend more time on obtaining tangible market touch, explore multiple marketing \& sales channels, and to be flexible in adjusting their business model.
\end{abstract}


Keywords: SME, high-tech, market entry, internationalisation, entrepreneurship, USA.

\section{Introduction}

Small and medium sized enterprises (SME) constitute a substantial part of many economies in the world (e.g. Graham, 1999; SME Statistics for the UK, 2005; European Commission, 2003; Gunasekaran, 2000; Klonowski, 2007; van Stel et al., 2005). Also, several studies have indicated how SMEs, and high-tech SMEs in particular, have a significant impact on economic development (Audretch et al., 2002; Acs, 1996; Carlsson, 1999; Acs et al., 1999; Pellikka \& Lauronen, 2007). Relatively large amount of product or service related development takes place in the high-tech oriented SME sector.

Typically, companies start their internationalisation close to home markets and in markets resembling their own (Johnson \& Tellis 2008). Some studies have suggested that the sequential path of internationalisation is determined by cultural distance (Czinkota, 1982) in addition to geographic proximity. Cultural similarities for example, may lead US firms to trade with Canadian, European countries to trade with one another, and Japanese firms to focus on Asia (Johansson 2006). In traditional internationalisation theories (Bilkey and Tesar, 1977; Cavusgil, 1980; Johanson and Vahlne, 1977; Johanson and Wiedersheim-Paul, 1975; Brewer, 2007), differences among countries are conceptualised as 'psychic distance'. The Uppsala internationalisation model (Johanson and Wiedersheim-Paul, 1975) proposes that firms first enter nearby countries within a low psychic distance, because their knowledge over these countries is better available and the business practices in these countries are easier to understand. This distinguishes it from cultural distance, which examines differences in cultural values between countries (Sousa and Bradley, 2006). However, these types of traditional one-best-way approaches have been shown to have very little competitive advantage. Rather, they mostly just describe what both the winners and losers do, not adequately distinguishing one from the other (Autio et al., 2000).

The international business literature has also presented several situation-specific entry models for successful new market entries (e.g. Ghauri \& Holstius, 1996; Pan \& Tse, 2000; Rodriquez-Pinto et al., 2007; Whitelock \& Jobber, 2004). These studies have segmented the impact of inter-company factors, business networks, industry-specific factors, and culture-specific factors. The models typically entail proceeding step-by-step, including varying degrees of resource commitment, risk exposure, control, and profit return. These models give a faulty notion, that by proceeding step-by-step you will succeed. Darling and Seristo (2004) note that the conception of overall process is an important element, as these hierarchical models are simplifications after all.

Leifer et al. (2000) suggest that a non-systematic intuitive process of parallel uncertainty reduction works better than systematic, engineering-oriented problem solving approaches in the case of high ambiguity. Market and economic conditions change continually requiring global business firms to change along with them (Cateora and Graham, 2002).

Makela and Maula (2005; 2008) have studied how foreign venture capitalists influence internationalisation. They found out that foreign venture capitalists located in 
the target market can be valuable for the venture. However, foreign investors have a tendency to drive portfolio companies towards their home markets, and the benefits may turn into disadvantages if the target market that best fits the company is different.

Contrary to traditional internationalisation models, high-tech SMEs are forced to operate globally to find customers for their niche products in order to succeed in tough international competition (Bell, 1995, Bell et al. 2003, Lindqvist, 1988, Ojala and Tyrvainen 2007, Dowling and Welch 2004). These companies are thus forced to enter and conduct business in countries with a greater psychic distance, making their internalisation even more challenging (Crick \& Spence, 2005). Ojala (2007) has studied the internationalisation of Finnish software (SW) companies and has found that the majority start their foreign direct operations by entering into a country that provides large markets for their niche products - namely the USA, Japan, and the UK. This may require discovering new market demands, learning new ways of thinking and doing business before being successful. For instance, Bell (1995) found that the firms' internationalisation behaviour is more related to customers' followership, niche markets, and industry-specific characteristics than to the more general psychic distance between countries. The high-tech SMEs' challenge is made even greater by the scarcity of resources. Mostly SMEs do not have the time for training of the same type or scale as multinational corporations (Dowling and Welch, 2004).

Literature uses the term born global for companies that adopt an international or even global approach right from their birth or very shortly thereafter (e.g. Madsen and Servais, 1997; Autio et al., 2000; Knight and Cavusgil, 1996; Oviatt and McDougall, 1994; Rennie, 1993). Literature typically studies the mechanisms behind internationalisation of companies, but does not sufficiently explain the criteria to differentiate winning approaches from less successful ones (e.g. Kuivalainen et al., 2007; Prange and Verdier, 2010).

This article concentrates on high-tech SMEs and their internationalisation efforts, especially the US entry. Regardless of the existing academic internationalisation models, company executives indicate that they are still lacking in practical advice on how to best internationalise. The authors are responding to this plea for practical case examples on new market exploration. This study utilises action research methodology and is conducted among a large number of Finnish high-tech companies attempting to internationalise their operations to the USA, covering both successful and unsuccessful cases. Thus, the findings are based upon experience in what has worked in practice and what has not. The article describes the difficulties faced by these companies as well as their successes. It analyses their processes and methods, and finally suggests a success producing internationalisation approach.

\section{Literature review}

Market entry modes have already been studied for decades (e.g. Johanson and Wiedersheim-Paul, 1975; Cavusgil, 1980; Crick and Spence, 2005; Morschetta et al., 2010). Some earlier internationalisation models, Uppsala (e.g. Johanson and Wiedersheim-Paul, 1975) and innovation-related (e.g. Cavusgil, 1980), portray firms becoming international in a slow and incremental manner. This slowness is explained by lack of knowledge on foreign markets, high uncertainty, and such (Madsen and Servais, 1997; Andersen, 1993). Some newer models contradict these systematic models in the 
sense that firms do not necessarily follow a systematic and sequential process (e.g. Crick and Spence, 2005). These firms, referred to as born globals by some researchers, adopt an international or even global approach right from their birth or very shortly thereafter (Madsen and Servais, 1997). According to Schwens and Kabst (2010), however, technology firms do not necessarily follow a single model, but combine entrepreneurial and process practices of different models.

In general, born globals do not have deeply-rooted administrative heritage typical for long-established businesses (Collis, 1991). Companies that venture abroad late in their existence must unlearn routines rooted in domestic operations, as these established businesses have more constraints, potentially influencing their strategic choices. New markets require practices that may conflict with existing operations and management's mindsets (Autio et al., 2000; Barkema and Vermeulen, 1998). The age, size, and limited resources are not necessarily barriers to internationalisation of a firm (Knight et al., 2004).

Literature discusses factors that support successful internalisation. Butler et al. (2010) argue that being able to cope with uncertainty is important especially in the early phases of internationalisation. When entering new markets a firm must aim to learn and react to internal and external factors in various ways (Crick and Spence, 2005; Kocak and Abimbola, 2009). Madsen and Servais (1997) highlight that it is important to be very close to customers when entering new markets.

Firms must possess specific knowledge-based internal organisational capabilities supporting success in foreign markets (Knight and Cavusgil, 2004; Madhok, 1997). Kuivalainen et al. (2010) specially emphasise the importance of international experience and financial resources \& skills. Companies must obtain external knowledge in order to meet the requirements of versatile knowledge. This is highlighted, should a company be small. The composition of top management team, its international experience and nationality diversity, influences international decision-making with regard to choice of entry mode. (Nielsen and Nielsen, 2010; Nielsen, 2010). Consequently, it is vital to recruit expertise from one's target market. However, Zhou et al. (2007) argue that homebased social networking also plays a crucial role for obtaining required competence. According to Sharma and Blomstermo (2003) companies should possess international market knowledge before their first foreign market entry. Also, earlier research has found that diverse relationship building and networking are important when examining sales \& marketing channels (Coviello and Munro, 1997; Brown et al., 2010).

When considering networking, a recommenced approach is to use multiple channels, instead of relying on a single avenue (Gabrielsson and Kirpalani, 2004; Johanson and Vahlne, 2003). Multi-channel approach is recommended even when using modern Internet based sales-channels that should only be considered as a part of a channel portfolio (Gabrielsson \& Gabrielsson, 2010).

\section{Research process}

This inductive research is based on long-term cooperation with Finnish high-tech SMEs aiming to grow and globalise their business. The research consisted of 49 companies and total of 60 US entry episodes between 1995 and 2009. The authors have been involved with all the studied companies for extended period of time ensuring a good level of visibility over their internationalisation efforts. 
The research sample consisted of high-tech SMEs with revenues from $\$ 0$ to $\$ 80 \mathrm{~m}$ during the study period, the median being less than $\$ 5 \mathrm{~m}$. In 34 of the 49 subject companies, one or more of the authors were deeply involved in some aspect of the companies' business development and thus were deeply familiar with the globalisation events as they occurred. In the remaining 15 , one or more of the authors had extensive access to company personnel for gathering research data.

The action research approach of the study was based upon the authors' tangible cooperation with the sample companies for extended periods of time ensuring a good level of visibility over their internationalisation efforts. Action research is a longitudinal, collaborative in-situ approach of performing research observation and data collection while actually involved in the phenomena or system being studied (Coghlan and Brannick, 2001; French and Bell, 1973).

The research consisted of a) analysing criteria that differentiate winners from losers, b) classifying each company's position on the identified criteria, c) rating the degree of each company's success or failure, d) conducting post-reflection interviews with the companies. The classifications employed in this research build on the professional knowledge of the researchers. These criteria/classifications were obtained by each researcher first conducting analysis independently, after which the research group discussed resulting in a common understanding, i.e. consensus. At least 4 persons in each company and at least one external person relevant to the company's business were interviewed. These interviews were conducted both during the internationalisation episodes and after the episode. Post-reflection interviews are also seen as an important aspect of action research (Mezirow, 1991).

The study also included cooperation with the Finnish Funding Agency for Technology and Innovation (Tekes), which provided extensive access to information benchmarking the success or failure of high-tech companies at the national level.

The role of the first author can be best described as an active business consultant, but with extensive academic credentials. He is an American with extensive history working with Finnish high-tech SMEs. The other authors are Finnish with both business and academic experience. All of the authors have doctoral degrees and business teaching and research experience as well as experience in the internationalisation efforts of Finnish high-tech companies.

\section{Results and discussion}

\subsection{Analysis of sixty high-tech USA market entries}

Table 1 summarises the characterisations of the 60 separate globalisation ventures of the 49 studied SMEs. The horizontal axis describes the ratings of the relative success of each of the 60 entry ventures, using the following five categories:

1. Complete business failure

2. Entry failure and unintentional withdrawal from USA market

3. Intentional withdrawal

4. Marginal success (remain in USA market with marginal performance) 
5. Major success (high performance and/or growth)

The three first categories include different levels of failures, while the latter two describe minor or major success. $65 \%$, or 39 episodes, of the 60 sample market entry episodes were rated as failed, and $35 \%$, or 21 episodes, were judged somewhat or very successful. 
Table 1. Different business approaches influencing the success / failure

\begin{tabular}{|c|c|c|c|c|c|c|}
\hline \multicolumn{2}{|l|}{ Approach } & $\begin{array}{l}\text { Complete } \\
\text { business } \\
\text { failure }\end{array}$ & $\begin{array}{l}\text { Entry failure } \\
\text { (unintentional } \\
\text { withdrawal from } \\
\text { target market) }\end{array}$ & $\begin{array}{c}\text { Intentional } \\
\text { withdrawal } \\
\text { (learning about } \\
\text { market) }\end{array}$ & $\begin{array}{l}\text { Marginal success } \\
\text { (survival level } \\
\text { performance \& } \\
\text { growth) }\end{array}$ & $\begin{array}{l}\text { Major success } \\
\text { (rapid growth, } \\
\text { high profit, } \\
\text { trade sale, IPO) }\end{array}$ \\
\hline \multicolumn{7}{|l|}{ Entry approach } \\
\hline \multirow[t]{2}{*}{ Mentality \& mode } & Non-adaptive & 11 & 16 & 5 & 3 & 0 \\
\hline & Adaptive & 1 & 3 & 3 & 8 & 10 \\
\hline \multirow[t]{3}{*}{ Market responsiveness } & Rigid & 9 & 14 & 2 & 0 & 0 \\
\hline & Reactive & 3 & 4 & 5 & 5 & 4 \\
\hline & Proactive & 0 & 1 & 1 & 6 & 6 \\
\hline \multicolumn{7}{|c|}{ Organisation \& management approach } \\
\hline \multirow[t]{3}{*}{ Nationality } & Finnish only & 5 & 6 & 1 & 1 & 0 \\
\hline & American only & 2 & 5 & 3 & 1 & 0 \\
\hline & Multi-national & 5 & 8 & 4 & 9 & 10 \\
\hline \multirow[t]{2}{*}{ Functional expertise } & Engineer / scientist only & 6 & 10 & 2 & 0 & 0 \\
\hline & Multi-functional & 6 & 9 & 6 & 11 & 10 \\
\hline \multirow[t]{3}{*}{ Outside expertise } & Employee only & 9 & 9 & 5 & 2 & 0 \\
\hline & Knowledge consultant (technology) & 2 & 6 & 2 & 4 & 5 \\
\hline & Process consultant (business) & 1 & 4 & 1 & 5 & 5 \\
\hline \multirow[t]{2}{*}{ Board of directors } & No / Weak board & 12 & 14 & 7 & 5 & 0 \\
\hline & Strong board & 0 & 5 & 1 & 6 & 10 \\
\hline
\end{tabular}


The vertical axis of table 1 describes the business approaches for launch mentality \& mode, response to market, and organisation \& management that were identified as the best criteria to differentiate winners from losers. Organisational \& management approach includes four characteristics of management nationality, functional expertise, use of outside expertise, and capability of the board of directors.

1. The mentality \& mode covers two approaches of non-adaptive and adaptive. Nonadaptive entry approach means that a company would just attempt selling in the USA the way they did at home. Thus the company assumes that the markets were the same and that the home approach would work also in the USA. Adaptive entry approach means that the market entrants initially assumed that the USA markets were very different and initially set out to explore and learn about differences in technologies, marketing \& sales, management / business practices and methods. Eventually the company comes up with a new way of running business for the new market, based on the gained learning.

2. Market responsiveness means the degree of a company anticipating, reacting or responding to events in the market place. The companies were divided into three categories of rigid, reactive or proactive.

3. The organisation \& management approach covers the expertise a company seeks for its business organisation. This included four characteristics of management nationality, functional expertise, use of outside expertise, and the board of directors.

$82 \%$ (32 out of 39) of the failure cases used the non-adaptive launch mode, where their approach was to sell in the US the same way as they were used to at home, without conducting new market research. These cases failed to understand that the markets are different and that the company may need to adapt to different market needs. On the other hand, $86 \%$ (18 out of 21) of the successful cases used the adaptive launch mode by intentionally getting close to the new market utilising market research and expertise to adapt to the new needs. This approach included renewing the business model when necessary. The results indicate a clear difference in favour of adaptive over non-adaptive launch mode.

Most surprising was the fact how prevalent the non-adaptive approach was in this sample. A full $58 \%$ (35 out of 60) of the cases just kept operating, in the USA as at home. They were reluctant to spend money on market exploration or research, instead they hired inexpensive commissioned sales people. They stubbornly continued this pattern of behaviour even in the face of continuing failure.

$64 \%$ (25 out of 39) of the failure cases used the rigid approach as their response to market, not adapting their operations based on experience gained in the field. None of the successful companies used the rigid approach. $31 \%$ (12 out of 39) of the failure cases used the reactive strategy, attempting to react to the experienced differences, while only 5\% (2 out of 39) of the failures used a proactive approach, intentionally exploring the market and developing the strategy accordingly. On the other hand, $43 \%$ (9 out of 21) of the successful companies used the reactive strategy. A total of $57 \%$ (12 out of 21) of the successful cases used the proactive approach. Clearly, listening and reacting to the marketplace is an important for new entrants to the USA market.

The successful and failed companies also had differences in their organisation and management. $58 \%$ (22 out of 39) of the failures used a nationality-wise homogeneous personnel strategy in their US activities, either all Finnish (31\% of the cases) or all American 
(26\%), while only $10 \%$ (2 out of 21 ) of the winners did so. $90 \%$ (19 out of 21 ) of the successful cases used a multi-national personnel strategy.

In relation to functional expertise, $46 \%$ (18 out of 39) of the failures used an engineercentric staffing approach, while none of the winners did so. $100 \%$ of the successful cases used a multi-functional staffing policy, including experienced business and marketing personnel. Only $54 \%$ (21 out of 39) of the losers used this approach.

In relation to the use of outside expertise, $59 \%$ (23 out of 39) of the failed cases used an employee only expertise sourcing policy, not willing to pay for external expertise. Only $10 \%$ (2 out of 21) of the winners used this approach. $90 \%$ (19 out of 21) of the winners acquired the expertise they needed from outside.

$85 \%$ (33 out of 39) of the failures had no board of directors, or a weak one. $76 \%$ (16 out of 21) of the successful companies used a strong board while only $15 \%$ (6 out of 39) of the losers did. Once again, the more professional, big business approaches to management and organisation issues seemed to distinguish winners from losers in a significant manner.

\subsection{Discussion and implications}

\subsubsection{Typical mistakes by the losers}

The losing high-tech companies have difficulties in perceiving the implications of the market size difference for their business. In some cases, the entire business model of the company may be necessary to be reconsidered. For example, a company that has been a systems supplier in the home market might need to reconsider their role and become a device or even component supplier when entering the USA. In addition, USA being a large market, domestic differences should be considered and not to expect it to be homogenous internally. Competitive situation may also be different in different parts of the country.

The losing high-tech SMEs are technologically oriented and even managed by engineers. These companies often spend too much time on getting the product ready for the USA while still at home before actually exploring the US market. Products may need to be localised for the US market and it would be better for the product designer to learn about this sooner rather than later. It would be a good advice to go to the US earlier and adjust product for the market.

During the research it was realised that typical losing high-tech SMEs stubbornly followed their engineering oriented mentality. The reaction by potential American customers and partners is best described by the following comment "These guys are really good with their products and technology, but are hard to work with because they do not work well with others and_do not do_what we want. Though 'good guys,' they behave like 'arrogant engineers' and don't hear us. So we will work with other, more service oriented folks if possible, when differentiating technology is not the key to success."

Too often, the losing high-tech entrepreneurs believe that a good product sells automatically. As a consequence their market launch is too weak and may only contain a booth at a couple of trade shows. Often, this only generates an initial bubble of interest and maybe some product awards, misleading companies on the market potential. Late and equally weak sales campaigns tend to follow the soft trade show launches. Instead of one's own effort, a simple guaranteed solution, "silver bullet", is assumed by seeking USA "partners who will save us money and take care of our interests". Countless times entrepreneurs have said: "we gave them half of our price as discount, they promised great things, but nothing happened." All US 
sales managers are used to this type of situations and know how to handle it. Also, entrepreneurs rarely understand the scale of investment required for entering the US market. The owners are typically not willing to invest enough money nor are willing to sell shares, making the game too small for success. The losing high-tech SMEs tend to overemphasise tradeshows, single distribution channel, single partner, or single local salesman. Relying on a single avenue combined with rigid business model results in poor sales, poor understanding of markets, channels and customers.

The losing companies tend to overemphasise planning for the USA entry, which is typically conducted from home, before exploring the market locally. Unfortunately, misunderstanding the US marketplace by skipping market exploration and business development is often coupled with weak sales and marketing efforts. Experienced American entrepreneurs would generally not dream of starting business operations in a market segment with which they were not intimately familiar and for which they did not have good contacts. No one can develop this touch from a distance, from outside the market, no matter how smart they are, or how good the statistics, reports or other, commonly available market intelligence. After all, by the time market data is well known and gets into commonly available reports, it is often too old to be of much competitive value. The main reason for these mistakes is lack of business experience, particularly international business experience, both at board as well as at management levels.

Based on this study, the losing companies tend to be linear, systematic and methodical. The familiar and comfortable "engineering development-type" processes, such as detailed planning before execution just do not always function.

The key mistakes of the losing high-tech SMEs entering the US markets:

- Deficient understanding of the US markets;

- Deficient competence and experience from international business in the board and management;

- Overemphasising technology, underemphasising customer requirements;

- Concentrating too long on the home markets and in-house product development;

- Too low investment in marketing and sales.

As a summary, the losing approach is characterised by rigid, mechanical, non-exploratory, nonlearning, non-adaptive, linear step-wise processes, employed by the less successful USA market entrants, see Figure 1.

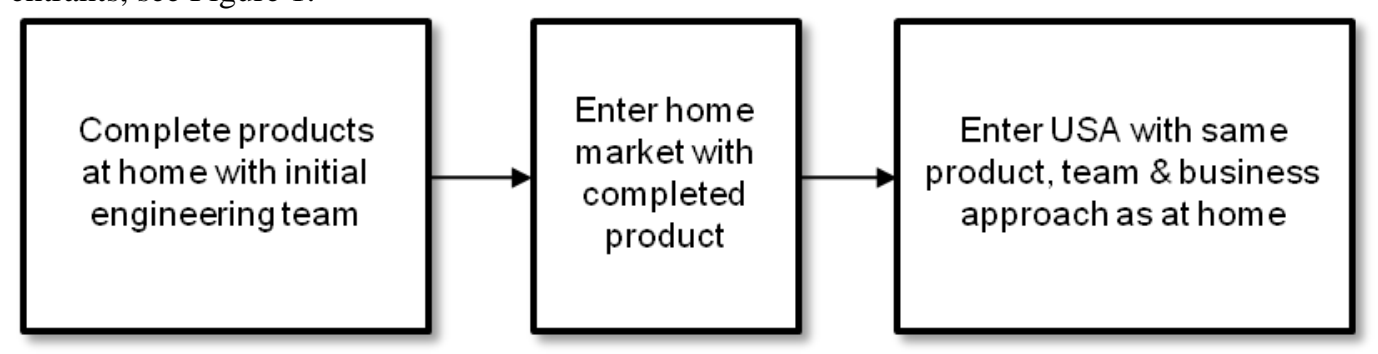

Figure 1. the losing approach 


\subsubsection{Winning approach}

The purpose of describing the winning approach is to condense the learnings from how the winners entered the US market. The most important learning for the companies is to leave the comfort of their home country and to go and learn firsthand of the US markets. The winners either expected, or soon found out, that the USA marketplace is a very different than at home. The losers did not expect this, and when confronted with it they stubbornly resisted facing reality.

The winning companies abandoned their strive for developing a perfect product and making perfect marketing plan before experiencing the market. Go to the US early, explore and learn, and only then plan. Products and business development activities can be adjusted to fit the realities of the market place instead of basing actions on uninformed and in some cases incorrect speculations. Business executives must expect a significant period of learning in the USA; must be ready to question all of their business assumptions; must plan on a period of exploration before they can hope to become successful in the US or any other foreign markets.

The winners realised that they must learn new and change in order to obtain success in the new market. They were willing to spend a lot of time, money and other resources getting close to the marketplace. They wanted to learn firsthand about these differences. The winners also experimented with changes and different solutions by making real modifications to their products, methods, organisations and even in their business model in order to produce success. The losers seldom changed but stuck with their initial thoughts and plans.

As an entrepreneur saw the above discussed: "The old paradigm tells that you will not execute successfully if you hadn't planned carefully. The new paradigm says that you can't plan successfully if you don't execute concurrently. If this paradigm shift is true, I have to change my behaviour a lot. I have to accept my mistakes and recover immediately. No, actually I have to stop getting anxious as a consequence of a mistake. Then, no need for recovering exists anymore. And I can use all my energy for execution."

This is what market entry to US is all about -optimum concurrent planning / evolutionary learning i.e. plan-during-execution rather than the traditional plan-then-execute process. This can be seen as a process for companies to gain the necessary market touch fast, inexpensively and pain-free. This approach functions well as it is a faster-to-market and faster-to-money process with lower time and money risk.

The winners invest more in marketing and sales than what initially seems appropriate. Losers' typical mistake is to just hire a couple of salesmen, indicates a lack of understanding of the US business practices and behaviour. The winners have realised that sales are frequently the most critical function in B-to-B business in the USA, with marketing playing an important support role depending upon the chosen sales channels.

Companies who have been successful in the USA and USA based mentors who have experience working with foreign companies are ready to help those planning a market entry. They will accelerate the process and reduce risk via their navigation and cultural translation assistance. The deficiencies in the company's and their managers' own knowledge and experience have been systematically identified and compensated by using those who have done the same before. The winners started from the very beginning to build the right expertise and global business culture into the company. Practically, this meant building cross-functional and multi-national teams, putting businessmen, marketers and foreigners into key positions along with the engineers. Losing companies followed the more familiar approach:"let's finish the product first then hire a couple of salesmen".

Main learnings from winning high-tech SMEs entering the US markets: 
- $\quad$ Go often to the USA and explore the market. Be flexible and be prepared to change the way you think according to the market. Have faith in your ability to navigate and learn;

- $\quad$ Aim towards networking to find customers and partners. Try to learn from them when and how to enter the USA;

- Try to obtain lead customers and utilise their feedback;

- $\quad$ Localise your product / service for the US market;

- $\quad$ Reconsider your business model;

- $\quad$ Establish US board of directors \&/or advisory council.

The results of this study indicate that the first goal once entering the US market is to get the first customer. The second task is to get feedback from your first customers through active communication, listen and learn. Utilise the obtained learning and develop your processes, products, marketing, sales etc. Pay special attention on localising your product for the US market. Service plays a crucial part in the US market; aim to develop it by acquiring expertise, and utilising your contacts.

Based on this study, companies should develop and scale their business model for the US markets. Consider the volume required to make the business profitable. High-tech SMEs may also find it necessary to change their business model.

The SMEs should seriously consider abandoning their native tendency to under invest in sales. It is not wise to rely on a single avenue in the US market, but rather to try multiple channels and segments and change the business model according to obtained knowledge. Companies also need to rearrange their organisation according to the new business model, and increase expertise of company board and management, through hiring people with US expertise.

Besides operative objectives, companies should develop tangible intuition over the US markets, business practices \& individual behaviour and strongly focus on selling.

As a summary, based on this study, the winning approach is best characterised by organicintuitive, evolutionary learning and iteratively adaptive entry processes employed by the successful USA market entrants, see Figure 2. The presented winning approach may initially feel somewhat chaotic and unplanned, however, it is proven to suit well in uncertain situations. Winners have realised that the customer is the king and that it is better to listen the customer instead of telling they are wrong and our technology is excellent. 


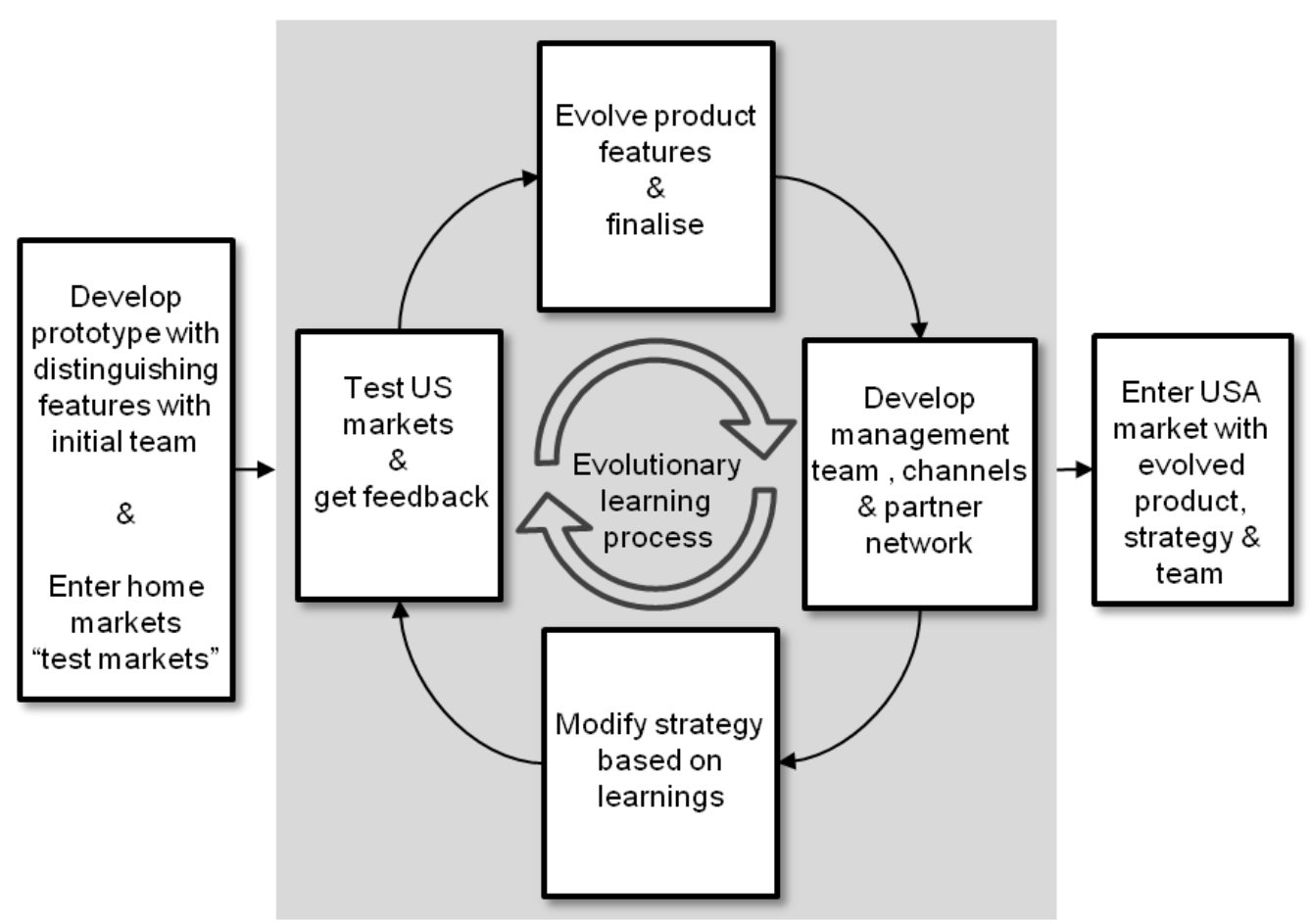

Figure 2. The winning approach

\section{Conclusions}

High-tech SMEs are having to expand rapidly outside their home markets in order to succeed in today's fragmented markets and fierce global competition. However, small companies have scarce resources causing any internationalisation efforts to be challenging. This study utilised action research to analyse 60 attempts of Finnish high-tech SMEs entering the US market. This article presents criteria for separating winners from losers. This provides new knowledge as earlier literature typically describes internationalisation attempts of companies without adequately separating success and failure.

Typical challenges of high-tech SMEs include, companies concentrating too long on their home markets and in-house product development prior to considering globalisation. Also, deficient understanding of the target market, combined with deficient competence and experience from international business in the board \& management causes difficulties. Hightech SMEs tend to be engineering oriented and invest too little in marketing and sales. Managers of high tech firms wishing to internationalise can improve their chances for success by following the approaches adopted by successful companies. Analysing failures is also beneficial in order to avoid typical mistakes.

This study supports claims that old market entry models, such as the Uppsala model, are not suitable for high-tech SMEs. Instead, SMEs must aim to enter their markets rapidly and not to follow a step-by-step process. This research proves that high-tech SMEs may find evolutionary learning beneficial, as the final business success is often a result of serendipitous evolution, i.e. a combination of luck and persistent intentional development. 
This study indicates that companies should consider starting internationalisation process earlier, be proactive, and utilise the learning-by-doing method. Companies may also have a need to obtain better business knowledge of their target market, acquire expertise to their board \& management and network locally. This has also been identified by a number of other authors, e.g. Nielsen (2010), Coviello and Munro (1997), Zhou et al. (2007), and Sharma and Blomstermo (2003). Continuous evolutionary learning is required to obtain relevant information and market touch to adjust your business model. Also other authors emphasise the importance of learning and reacting to internal and external factors when entering new markets (Crick and Spence, 2005; Kocak and Abimbola, 2009). The companies should not rely on a single avenue, but rather explore multiple marketing and sales channels and try diverse approaches in different customer segments. This view is supported also by other researchers, e.g. Gabrielsson and Kirpalani (2004), Johanson and Vahlne (2003), and Gabrielsson and Gabrielsson (2010).

Even though this study considered the US entry attempts of Finnish high-tech companies, similar challenges are faced by companies of any origin. The chosen research method has its limitations in relation to objectivity and further research is required to confirm full generalisation of the results. The study could also be expanded to cover other target markets and countries of origin.

\section{Acknowledgements}

The authors would like to thank the case companies and the Finnish Funding Agency for Technology and Innovation (Tekes), for providing an access to information. The authors would also like to thank Professor Emeritus Karl Vesper of the University of Washington for his valuable comments.

\section{References}

Acs, Z.J., 1996. Small firms and economic growth. Admiraal P.H. (ed), Small Business in the Modern Economy, Blackwell Publishers, Oxford, UK.

Acs, Z., Carlsson, B. and Karlsson, C. (1999) The Linkages Among Entrepreneurship, SMEs and Macroeconomics, Cambridge, UK: Cambridge University Press.

Andersen, O. (1993) 'On the internationalization process of firms--a critical analysis', Journal of International Business Studies, Vol. 24, No. 2, pp. 203-209.

Audretch, D.B. and Carree, M.A., van Stel, A.J. and Thurik, A.R. (2002) 'Impeded Industrial restructuring: the growth penalty'. Kyklos, Vol. 55, No. 1. p. 81-97.

Autio, E., Sapienza, H.J. and Almeida, J.G. (2000) 'Effects of Age at Entry, Knowledge Intensity, and Imitability on International Growth', The Academy of Management Journal, Vol. 43, No. 5, pp. 909924.

Barkema, H.G. and Vermeulen, F. (1998) 'International Expansion through Start up or Acquisition: A Learning Perspective', The Academy of Management Journal, Vol. 41, No. 1, pp. 7-26.

Bell, J. (1995) 'The internationalization of small computer software firms A further challenge to "stage" theories', European Journal of Marketing, Vol. 29 No. 8, , pp. 60-75.

Bell, J., McNaughton, R., Young, S., \& Crick, D. (2003). Towards an integrative model of small firm internationalisation. Journal of International Entrepreneurship, 1(4), 339-362.

Bilkey, W. and Tesar, G. (1977) The export behaviour of smaller sized Wisconsin manufacturing firms. Journal of International Business Studies 8(1), 93-98. 
Buckley, P.J. and Casson, M.C. (1998) 'Analyzing foreign market entry strategies: Extending the internalization approach', Journal of International Business Studies, Vol. 29, No. 3, pp. 539-561.

Butler, J.E., Doktor, R. and Lins, F.A. (2010) 'Linking international entrepreneurship to uncertainty, opportunity discovery, and cognition', Journal of International Entrepreneurship, Vol. 8, No. 2, pp. 121-134.

Brewer, P. A. (2007) Operationalizing psychic distance: A revised approach. Journal of International Marketing 15(1), 44-66.

Brown, P., McNaughton, R.B. and Bell, J. (2010) 'Marketing externalities in industrial clusters: A literature review and evidence from the Christchurch, New Zealand electronics cluster', Journal of International Entrepreneurship, Vol. 8, No. 2, pp. 168-181.

Carlsson, B. 1999. Small business, entrepreneurship, and industrial dynamics, Z. Acs (ed.), Are Small Firms Important?. Kluwer Academic Publisher.

Cateora, P.R. and Graham, J.L. (2002), International Marketing, 11th ed., McGraw-Hill Publishing, New York, NY.

Cavusgil, S.T. (1980) 'On the internationalization process of firms', European Research, Vol. 8, No.6, pp. 273-281.

Coghlan D, Brannick T (2001) Doing Action Research in Your Own Organization. Sage Publications.

Collis, D.J. (1991) 'A resource-based analysis of global competition: The case of the bearings industry', Strategic Management Journal, Vol. 12, No. S1, pp. 49-68.

Coviello, N. and Munro, H. (1997) 'Network relationships and the internationalisation process of small software firms', International Business Review, Vol. 6, No. 4, pp. 361-386.

Crick, D. and Spence, M. (2005) 'The internationalisation of 'high performing' UK high-tech SMEs: a study of planned and unplanned strategies', International Business Review, Vol. 14, No. 2, pp. 167185.

Czinkota, MR. (1982), Export Development Strategies: U.S. Promotion Policies. New York: Praeger Publishers.

Darling J. R. \& Seristo H. T. 2004. Key steps for success in export markets - A new paradigm for strategic decision making. European Business Review. Vol. 16 No. 1, pp. 28-43.

Dowling, P. J. and Welch, D. E. (2004) International Human Resource Management: Managing People in a Multinational Context. Thomson Business Press, London.

European Commission 2003. SMEs in Europe 2003. Observatory of European SMEs. 2003/7.

French WL, Bell C (1973) Organization development: behavioural science interventions for organization improvement. Prentice-Hall.

Gabrielsson, M. and Kirpalani, V.H.M. (2004) 'Born globals: How to reach new business space rapidly', International Business Review, Vol. 13, No. 5, pp. 555-571.

Gabrielsson, M. and Gabrielsson, P. (2010) 'Internet-based sales channel strategies of born global firms', International Business Review, Article in Press, Corrected Proofs.

Ghauri, PN and Holstius K (1996) The role of matching in the foreign market entry process in the Baltic States, European Journal of Marketing, Vol. 30 No. 2, 1996, pp. 75-88.

Graham, P. (1999) 'Small business participation in the global economy', European Journal of Marketing, Vol. 33, Nos. 1-2, pp.88-102.

Johansson, JK. (2006) Global Marketing, 4th ed. Homewood, IL: McGraw-Hill/Richard D. Irwin.

Johnson, J. \& Tellis GJ. (2008) Drivers of Success for Market Entry into China and India, Journal of Marketing,Vol. 72, pp. 1-13.

Johanson, J. and Vahlne, J.-E. (2003) 'Business relationship learning and commitment in the internationalization process', Journal of International Entrepreneurship, Vol. 1, No. 1, pp. 83-101. Johanson, J. and Wiedersheim-Paul, F. (1975) The internationalization of the firm: Four Swedish cases. Journal of Management Studies 12(3), 305-322.

Klonowski, D. 2007. 'High-tech incubators in transition economies: a case study of iPark, a venture capital backed internet holding company’, Int. J. Technoentrepreneurship, Vol. 1, No. 1, pp. 21-34. 
Knight, G.A. and Cavusgil, S.T. (1996) 'The born global firm: A challenge to traditional internationalization theory, Advances in International Marketing, Vol. 8, pp. 11-26.

Knight, G.A. and Cavusgil, S.T. (2004) 'Innovation, Organizational Capabilities, and the Born-Global Firm', Journal of International Business Studies, Vol. 35, No. 2, pp. 124-141.

Knight, G., Madsen, T.K. and Servais, P. (2004) 'An inquiry into born-global firms in Europe and the USA', International Marketing Review, Vol. 21, No. 6, pp. 645-665.

Kocak, A. and Abimbola, T. (2009) 'The effects of entrepreneurial marketing on born global performance', International Marketing Review, Vol. 26, No. 4/5, pp. 439-452.

Kuivalainen, O., Sundqvist, S. and Servais, P. (2007) 'Firms' degree of born-globalness, international entrepreneurial orientation and export performance', Journal of World Business, Vol. 42, No. 3, pp. 253-267.

Leifer, R., McDermott, C.M., O'Connor, G.C., Peters, L.S., Rice M.P. and Veryzer, R.W. (2000) 'Radical Innovation: How Mature Companies Can Outsmart Upstarts' Harvard Business Press; 1st ed. Boston, MA.

Lindqvist, M. (1988) Internationalization of small technology based firms: Three illustrative case studies on Swedish firms. Research Papers 88/15, Sweden: Stockholm School of Economics.

Madhok, A. 1997. Cost, value and foreign market entry mode: the transaction and the firm. Strategic Management Journal, Vol. 18, 39-61

Madsen, T.K. and Servais, P. (1997) 'The Internationalization of Born Globals: an Evolutionary Process?', International Business Review, Vol. 6, No. 6, pp. 561-583.

Mezirow, J. (1991), Transformative Dimensions of Adult Learning, Jossey-Bass, San Francisco, CA,

Morschetta, D., Schramm-Klein, H. and Swoboda, B. (2010) 'Decades of research on market entry modes: What do we really know about external antecedents of entry mode choice?', Journal of International Management, Vol. 16, No. 1, pp. 60-77.

Mäkelä, M.M. \& Maula, M.V.J. 2008. Attracting Cross-Border Venture Capital: The Role of a Local Investor. Entrepreneurship and Regional Development 20: 237-257.

Mäkelä, M.M. \& Maula, M.V.J. 2005. Cross-Border Venture Capital and New Venture Internationalization: An Isomorphism Perspective. Venture Capital: An International Journal of Entrepreneurial Finance 7(3): 227-257.

Nielsen, S. (2010) 'Top Management Team Internationalization and Firm Performance: The Mediating Role of Foreign Market Entry', Management International Review, Vol. 50, No. 2; pp. 185-206.

Nielsen, B.B. and Nielsen, S. (2010) 'The role of top management team international orientation in international strategic decision-making: The choice of foreign entry mode', Journal of World Business, Article in Press, Corrected Proofs.

Ojala, A (2007) Entry in a psychically distant market: Finnish small and medium-sized software firms in Japan, European Management Journal (2008) 26, pp. 135- 144.

Ojala, A., \& Tyrväinen, P. (2007). Market entry and priority of small and medium-sized enterprises in the software industry: An empirical analysis of cultural distance, geographical distance, and market size. Journal of International Marketing, 15(3), 123-149.

Oviatt, B.M. and McDougall, P.P. (1994) 'Toward a theory of international new ventures', Journal of International Business Studies, Vol. 25, No. 1, pp. 45-64.

Pan, Y. \& Tse, D.K. 2000. The Hierarchical Model of Market Entry Modes. Journal of International Business Studies, Vol. 31, 2000

Pellikka, J. and Lauronen, J. (2007) 'Fostering commercialisation of innovation in small high technology firms', Int. J. Technoentrepreneurship, Vol. 1, No. 1, pp.92-108.

Prange, C. and Verdier, S. (2010) 'Dynamic capabilities, internationalization processes and performance', Journal of World Business, Article in Press, Corrected Proofs.

Rennie, M.W. (1993) 'Global competitiveness: Born global', McKinsey Quarterly, September.

Rodrıguez-Pinto J and Gutierrez-Cilla, J and Rodriguez-Escudero, AI (2007) Order and scale of market entry, firm resources, and performance, European Journal of Marketing Vol. 41 No. 5/6, 2007 pp. 590-607. 
Schwens, C. and Kabst, R. (2010) 'Internationalization of young technology firms: A complementary perspective on antecedents of foreign market familiarity', International Business Review, Article in Press, Corrected Proofs.

Sharma, D.D. and Blomstermo, A. (2003) 'The internationalization process of Born Globals: a network view', International Business Review, Vol. 12, No. 6, pp. 739-753.

Small Business Service (SBS) 2005, Small and Medium Enterprise SME Statistics for the UK, Small $\begin{array}{llll}\text { Business Service } & \text { (SBS). } & \text { < Available }\end{array}$ http://www.sbs.gov.uk/sbsgov/action/layer?topicId=7000011759

Sousa, C. M. P. and Bradley, F. (2006) Cultural distance and psychic distance: Two peas in a pod?. Journal of International Marketing 14(1), 49-70.

Whitelock, J. \& Jobber, D. 2004. An evaluation of external factors in the decision of UK industrial firms to enter a new non-domestic market: an exploratory study. European Journal of Marketing. Vol. 38 No. 11/12, 2004. pp. 1437-1455

Zhou, L., Wu, W.-P. and Luo, L. (2007) 'Internationalization and the performance of born-global SMEs: the mediating role of social networks', Journal of International Business Studies, Vol. 38, pp. 673690 . 